\title{
Homework Process in Higher Education Scale (HPHES): A Validity and Reliability Study
}

\author{
Veda Yar Yildirim (iD) 1,
}

${ }^{1}$ Kahramanmaras Sutcu Imam University, Faculty of Education, Department of Educational Sciences, Kahramanmaras, Turkey

\section{ARTICLE HISTORY}

Received: May 27, 2020

Revised: Nov. 08, 2020

Accepted: Jan. 07, 2021

Keywords:

Homework,

Scale,

Higher Education,

Validity,

Reliability.

\begin{abstract}
The aim of this study was to develop a scale to measure the process of receiving and completing homework from the perspective of university students, and to conduct its validity and reliability analyses. Two different sample groups were formed in order to develop the Homework Process in Higher Education Scale (HPHES). Students studying in different faculties in four different universities in the 2019-2020 academic year were included in the sample. The sample consisted of 368 students for Exploratory Factor Analysis (EFA) and 400 students for Confirmatory Factor Analysis (CFA). In the EFA, it was determined that the scale had a five-factor structure with 28 items. This structure was evaluated using CFA. When the fit indices of the resulting model were examined, the following results were obtained: $\chi^{2} / d f=2.36<4 ; \mathrm{CFI}=0.91 ; \mathrm{TL}=0.90 ; \mathrm{RMSEA}=0.05$; $\mathrm{SRMR}=$ 0.05. The structure was confirmed using CFA. Cronbach's Alpha reliability coefficient results calculated for the scale were verified with composite reliability coefficients. The convergent validity was tested by calculating average variance extracted (AVE) of each factor. The results of validity and reliability study of the HPHES showed that it was a valid and reliable measurement tool with five factors and 28 items. The subject of homework in higher education can be examined in terms of different variables using the HPHES.
\end{abstract}

\section{INTRODUCTION}

Homework has always been a high priority in the education system. In particular, homework may be more important than it was in the past due to recently increasing chaos in the external world. Homework generally indicates a task, duty or behavior which must be carried out according to a set of rules and instructions (Turkish Language Assosication, 2020). The concept of homework in education can be defined as the tasks given to students by teachers to complete in their extra-curricular time (Cooper, 1989; Li, Bennett et al., 2018). In one study on higher education, the students perceived their own independent studying as homework (Murtagh, 2010). Other students have been unhappy about having too much homework and thus not being able to participate in leisure activities (Núñez et al., 2015). Although homework is one of the key and indispensable elements in learning and teaching processes, students have often complained about it (Ünal et al., 2018; Hyman et al., 2005).

CONTACT: Veda Yar Yıldırım $\bigotimes$ vedayaryildirim@gmail.com Faculty of Education, Department of Educational Sciences, Kahramanmaras, Turkey 
Baran (2019) drew attention to the history of the homework and stated that homework has been part of the education system for more than a century. Both its good and bad sides have been discussed; for example, pioneering educators carried out campaigns in America in the 1940s on the basis of the idea that homework harmed children and their families. It has also been stated that giving students less homework after the 1980s caused problems in the education system, and that this was the reason for its subsequent increase thereafter. Nowadays, distance learning is becoming more and more common in higher education. However, online homework can have disappointing results (Xu et al., 2018). These results show that, considering the processes related to homework given in higher education, the subject of homework is not given enough importance.

The positive effects of homework are not just academic. Homework also has positive nonacademic effects on students, including improved self-management and self-discipline, better time management, more curiosity, and more independence in problem-solving (Cooper, 1989; 2001). Studies have shown that well-prepared homework positively affects students' skills of self-regulation, their academic self-efficacy, responsibility for their own learning, high-level thinking skills, effective learning strategies, and that it develops the habit of independent study (Duru \& Segmen, 2017, as cited. Ünal, Yıldırım, and Sürücü, 2018). In another study conducted with middle school students, homework was found to improve academic achievement and produce a number of benefits (Yar Yıldırım, 2018). Similarly, Murillo and Martinez-Garrido (2014) stated that doing homework increased students' academic success.

There is various advice in the literature about the nature of giving homework. This can be summarized as follows:

1) Students like research-type homework. This is explained by the fact that they can easily find the information online that they need to complete their homework (Çakır \& Ünal, 2019).

2) When giving homework, the students' interests, level of development, access to materials, and how they will be supervised should all be taken into account (Arikan \& Altun, 2007).

3) When giving homework, it is necessary to explain the content of the homework, and it should be interesting, stimulating, well-defined, and encourage creativity (Yapıc1, 1995; Türkoğlu et al., 2007).

4) Homework is a cause of stress for both students and other interested parties (parents, teachers, etc.) (Baran, 2019).

5) Cooper and Kalish (2015) emphasized that there is a moderate relationship between homework and achievement, and stated that homework should not be privileged above other learning activities, such as playing games and learning social skills, in order to prevent homework from having any negative effects.

6) The continuity of education is important for students. Public or private holidays disturb the unity of learning. Any periods not spent in education can lead to forgetting past learning and a lack of motivation. When students return to school, they then have to repeat what they have already learned. To prevent this, a higher number of homework is usually given during holiday periods. However, this does not produce the desired effect (Cooper \& Kalish, 2015). Therefore, giving a lot of homework during the holidays does not serve any purpose.

7) Homework should be marked, and these marks should be given in a way which increases the success of students (Yapıc1, 1995; Türkoğlu et al., 2007).

8) Homework in higher education differs from homework in primary and secondary education. Homework in higher education is not intended to complete classroom learning (Bembenutty, 2005).

9) The student's attitude is important for homework to serve a purpose (Reisimer, 1999). 
Studies in higher education point out various issues that should be taken into consideration in terms of homework. University students are generally encouraged to do homework by educators. If, for example, they are required to spend two hours preparing for each one-hour course they attend, this could mean that they should be studying for 40 hours per week. However, the majority of students spend less than 15 hours a week on lessons and homework (Young, 2002). This can negatively affect their level of achievement. Low effort and little time for students to do homework are associated with low motivation and a low sense of responsibility (Flunger et al., 2017). In a study conducted with university students, the students stated that they had done most of their homework, and they attributed incomplete homework to external factors such as sickness, adapting to the course, and the difficulty of the homework (Li et al., 2018). One reason for not completing homework was excessive smartphone usage (Furst et al., 2018).

The most important challenge with regard to homework occurs in the evaluation process. Students may share their work with others before handling them in. This makes it difficult to evaluate their performance. The issue of academic honesty has thus been the subject of a number of studies on homework (Balbuena \& Lamela, 2015).

Homework is used as a form of learning at all levels of education. The quality of homework and the curricula implemented in higher education are assured by the European Credit Transfer System (ECTS). The ECTS is a student-centered system. According to the study by Şen et al., (2016), the time spent by students on homework is recorded in the system, but it is often not taken into account. Homework is a process, not a result. The perception of homework, the acts of setting the homework and completing it, as well as its benefits and the feedback provided to students are among the components of this process. A number of different scales in the literature have focused on homework and attitudes related to doing homework. Studies have also focused on its functionality. However, the studies assessing the use of homework in higher education by analyzing students' perceptions are not common. It is thought that the scale that will emerge with this research will contribute to the development of homework processes in higher education since processes that cannot be measured can be difficult to develop.

This scale, developed in this context, measures the perceptions of students attending higher education regarding the homework process. Perception is that people organize and interpret data transported to the sense organs through stimuli (Arkonaç, 1998: 65). Homework is a process that occurs with many sense organs, as explained above. Perceptions affect attitudes. Especially recently, in pandemic processes where homework is more involved in education, it is important to measure the perceptions of homework that may affect students' attitudes with different processes. The Homework Process in Higher Education Scale (HPHES) can be used to evaluate homework and all the processes involved from the perspective of the students. In this context, the aim of the study was to conduct validity and reliability analyses of the HPHES.

\section{METHOD}

This section provides information about the study groups, the process of developing the scale, and the data analysis.

\subsection{Sample}

To develop the HPHES, convenience sampling method was used to determine the sample of the study. This method allows data collection to be conducted more easily (Balc1, 2004). For this purpose, the sample consisted of the students studying at different faculties at Mustafa Kemal University, Nevşehir Hacı Bektaş Veli University, Tokat Gaziosmanpaşa University (TOGU) and Firat University in the 2019-2020 academic year. In the study, the data collected from two separate groups were analyzed. The sample groups consisted of 368 students for Exploratory Factor Analysis (EFA) and 400 students for Confirmatory Factor Analysis (CFA). 
Table 1 shows the data from the sample groups for EFA and CFA during the process of developing the HPHES.

Table 1. Data from the sample groups for EFA $(N=368)$ and CFA $(N=400)$ of the HPHES.

\begin{tabular}{|c|c|c|c|c|c|c|c|}
\hline \multicolumn{4}{|c|}{ Data from the sample for EFA } & \multicolumn{4}{|c|}{ Data from the sample for CFA } \\
\hline \multicolumn{2}{|l|}{ Variables } & $\mathrm{N}$ & $\%$ & Variables & & $\mathrm{N}$ & $\%$ \\
\hline \multirow[t]{3}{*}{ Universities } & Mustafa Kemal & 242 & 65.8 & \multirow[t]{3}{*}{ Universities } & Firat & 258 & 64.5 \\
\hline & Hacı Bektaş Veli & 126 & 34.2 & & TOGU & 142 & 35.5 \\
\hline & Total & 368 & 100 & & Total & 400 & 100 \\
\hline \multirow[t]{5}{*}{ Year } & 1 & 48 & 13.0 & \multirow[t]{5}{*}{ Year } & 1 & 99 & 24.8 \\
\hline & 2 & 122 & 33.2 & & 3 & 234 & 58.5 \\
\hline & 3 & 121 & 32.9 & & 4 & 67 & 16.8 \\
\hline & 4 & 77 & 20.9 & & Total & 400 & 100 \\
\hline & Total & 368 & 100 & & & & \\
\hline \multirow[t]{3}{*}{ Gender } & Male & 144 & 39.1 & \multirow[t]{3}{*}{ Gender } & Male & 142 & 35.5 \\
\hline & Female & 224 & 60.9 & & Female & 258 & 64.5 \\
\hline & Total & 368 & 100 & & Total & 400 & 100 \\
\hline \multirow[t]{11}{*}{ Faculty } & Education & 50 & 13.6 & \multirow[t]{11}{*}{ Faculty } & Education & 61 & 15.3 \\
\hline & $\begin{array}{l}\text { Science and } \\
\text { Literature }\end{array}$ & 61 & 16.6 & & $\begin{array}{l}\text { Science and } \\
\text { Literature }\end{array}$ & 172 & 43.0 \\
\hline & Theology & 27 & 7.3 & & Theology & 31 & 7.8 \\
\hline & Economics & 51 & 13.9 & & Economics & 30 & 7.5 \\
\hline & Fine Arts & 26 & 7.1 & & Sports Sciences & 97 & 24.3 \\
\hline & Architecture & 28 & 7.6 & & Other & 9 & 2.3 \\
\hline & Dentistry & 24 & 6.5 & & Total & 400 & 100 \\
\hline & Health Sciences & 26 & 7.1 & & & & \\
\hline & Conservatory & 26 & 7.1 & & & & \\
\hline & Veterinary & 24 & 6.5 & & & & \\
\hline & Total & 368 & 100 & & & & \\
\hline
\end{tabular}

As shown in Table 1, the study had two different samples. The first sample group was the group in which data were collected for EFA during the development of the HPHES. This group included 368 students studying at Mustafa Kemal University and Hacı Bektaş Veli University. The total number of the students from Mustafa Kemal University was 242 while 126 of the sample were studying at Hacı Bektaş Veli University. In the sample, 224 of these students were female and 144 were male. There were students in all years of study (first, second, third and fourth years). As seen in Table 1, the students were studying in 11 different faculties and colleges in the group in which the data were collected for EFA during the development of the HPHES. The second sample group was the group in which the data were collected for CFA during the HPHES's development. In this group, the 400 students were studying at Firat University and Tokat Gaziosmanpaşa University. The students who were studying at Firat University were 258 while 142 of them were studying at Tokat Gaziosmanpaşa University. In the same group, 258 of these students were female and 142 of them were male. There were students in the first, second and fourth years of study. As shown in Table 1, the students were studying at seven different faculties in this group in which the data were collected for CFA during the development of the HPHES.

As seen in Table 1, data were collected from 368 students for EFA and 400 students for CFA. This number was sufficient to develop a scale. According to the literature, a sample size larger than 300 is considered sufficient to obtain consistent results (Field, 2005; Tabachnick \& Fidell, 2001), and it is also stated that the number of samples should be above 100 or five times higher the number of items $(H o, 2006)$. In this study, the number of students from whom data were collected was nine times higher than the total number of items for EFA. The number of students 
from whom data were collected for CFA was approximately 13 times higher than the total number of items. When the data collected after the application were examined, 26 forms with problems such as missing information, giving two or more responses for one item, and giving the same response for each item were excluded from the evaluation.

\subsection{Development of the Scale}

Studies on the subject in question were reviewed during the development of the HPHES (Murillo \& Martinez-Garrido, 2014; Núñez et al., 2015; Flunger et al., 2017; Gündüz, 2005; Cooper, 1989; Türkoğlu et al., 2007; Çakır \& Ünal, 2019; Yapıc1, 1995; Yar Yıldırım, 2018; Edinsel, 2008). The parts of the European Credit Transfer System (ECTS) related to the process of evaluating homework in higher education were also examined. An item pool was created in line with the literature and expert opinions. The scale is a five-point Likert-type scale and consists of the following options: "strongly agree" (5), "agree" (4), "partly agree" (3), "disagree" (2), and "strongly disagree" (1). To develop the HPHES the content validity and face validity were tested by obtaining the opinions of one expert in the field of Curriculum and Instruction, one expert in the field of Educational Administration and Supervision, and one expert in the field of Measurement and Evaluation. To determine whether the items in the pretest form developed in line with the opinions and suggestions of the experts were understandable to the students, a pre-application session was conducted with 20 students. These applications were carried out by the researcher; the feedback of the students was also evaluated. As a result of the expert opinions, the 40 -item scale was finalized.

\subsection{Data Analysis}

At this stage, the construct validity and reliability studies of the scale were conducted. For the construct validity of the scale, the structure of the scale was first examined using EFA and then CFA was applied to determine whether the resulting structure was confirmed. In EFA analysis, maximum likelihood estimation method and direct oblimin rotation were applied. Maximum likelihood estimation method is one of the most preferred factoring techniques. With this analysis, it is possible to see the correlation coefficients between the factors and to test whether the factor loads are significant (Çokluk et al., 2010). The oblique rotation technique direct oblimin was used because the purpose of the research was to reveal a structure consisting of interrelated factors theoretically and the relationship between the factors was expected. This rotation technique is the only oblique rotation technique in SPSS (Can, 2014).

The reliability of the scale was tested with Cronbach's Alpha reliability coefficient and composite reliability coefficient. It is claimed that in multi-dimensional scales, the composite reliability gives a stronger reliability value than the alpha value (Şencan, 2005). For the internal validity of the items, the item-total correlations and 27\% low and high groups item analysis were examined. The relationship between the factors of the scale was also examined. In addition, convergent validity of the scale was tested by calculating average variance extracted (AVE) of each factor. The SPSS 22 program was used to analyze the data, and the Mplus 7.4 program was used for CFA. For EFA and CFA, analyses were conducted with two separate data sets. Composite reliability and average variance extracted (AVE) were calculated on excel 2010 . 


\section{FINDINGS}

This section presents the findings related to the validity and reliability analysis of the HPHES.

\subsection{Findings regarding the Content Validity of the Scale}

\subsubsection{Exploratory Factor Analysis}

Before the EFA was carried out to develop the HPHES assumptions that the absence of extreme values that may affect the results, fitting to the normal distribution, and the suitability of the sample size to factoring were tested. The Kaiser-Meyer-Olkin (KMO) test and Bartlett's sphericity test results are given in Table 2 .

Table 2. Kaiser-Meyer-Olkin (KMO) test and Bartlett's sphericity test results.

\begin{tabular}{ll}
\hline Kaiser-Meyer-Olkin sample suitability measure & .94 \\
Bartlett's sphericity test chi-squared value & 7837.54 \\
Degree of freedom & 780 \\
Significance level & 0.00 \\
\hline
\end{tabular}

According to the results of the KMO test, the KMO value was .94 and thus higher than .60 . This finding showed that the sample size was perfectly sufficient for factor analysis (Büyüköztürk, 2019). When the Bartlett's sphericity test results given in Table 2 were examined, it was determined that the test result is statistically significant. The chi-squared value was significant and at the level of .01, and the data had a multivariate normal distribution. In addition, Q-Q plots and histograms were also examined to test the normal distribution of the items. Boxplot is examined for extreme values. Skewness (-.30) and kurtosis (-.28) values between -1 and +1 is an indicator of normal distribution. The results of the analysis showed that the measurement tool was suitable for EFA (Büyüköztürk, 2019). Accordingly, data analysis was carried out with the entire data set.

In the EFA, eigenvalues, variances, and scree plots were examined to determine the number of factors related to the 40-item scale. A relationship between factors is expected in the study. In addition, it is also aimed to reveal a structure consisting of theoretically related factors. Therefore, the oblique rotation technique direct oblimin is used. This rotation technique is the only oblique rotation technique in SPSS (Can, 2014). In the first analysis, using the Direct Oblimin oblique rotation technique, seven factors with an eigenvalue greater than one and with a contribution to the variance of 60.256 were found.

However, when the items were evaluated in terms of the degree of cyclicality and factor loads, some items were cyclical (Çokluk et al., 2010) and some items had one or two other items in the factor that they depended on. It is stated in the literature that each factor should consist of at least three items for the factor to be stable (Velicer \& Fava, 1998). Therefore, a total of 12 items $(29,30,19,31,32,21,22,20,14,11,10$, and 7) were excluded, and the analysis was conducted again. Eigenvalues, explained variances, factor loads, the reliability coefficient, and item-total correlations for the final form of the factor structure determined by EFA are given in Table 3 below. 
Table 3. EFA results, reliability coefficient, item-total correlations for the HPHES.

\begin{tabular}{|c|c|c|c|c|c|c|c|c|c|}
\hline \multirow[b]{2}{*}{ 竞 } & \multirow{2}{*}{ 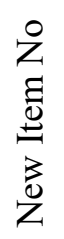 } & \multirow[b]{2}{*}{$\stackrel{\ominus}{\Xi}$} & \multirow[b]{2}{*}{ Items } & \multicolumn{5}{|c|}{ Factor Loads } & \multirow{2}{*}{ 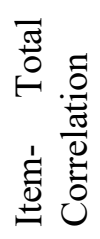 } \\
\hline & & & & 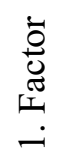 & 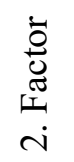 & 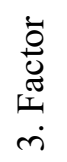 & 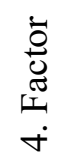 & 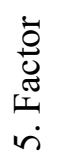 & \\
\hline \multirow{7}{*}{ 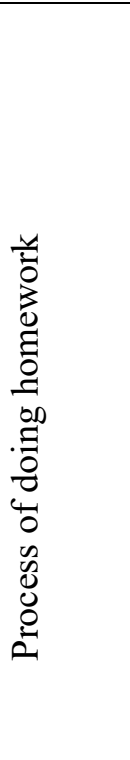 } & 1 & 37 & $\begin{array}{l}\text { Feedbacks on the homework should be } \\
\text { positive. }\end{array}$ & .65 & & & & & .60 \\
\hline & 2 & 35 & $\begin{array}{l}\text { In the process of doing the homework, the } \\
\text { teachers should allocate sufficient time for } \\
\text { the students for the necessary feedback. }\end{array}$ & .52 & & & & & .59 \\
\hline & 3 & 36 & $\begin{array}{l}\text { The process of doing homework brings } \\
\text { along other gains. }\end{array}$ & .52 & & & & & .65 \\
\hline & 4 & 38 & $\begin{array}{l}\text { After the homework, students should feel } \\
\text { pleased about their achievement. }\end{array}$ & .51 & & & & & .64 \\
\hline & 5 & 40 & $\begin{array}{l}\text { Homework should be applicable to daily } \\
\text { life after education process. }\end{array}$ & .51 & & & & & .63 \\
\hline & 6 & 33 & $\begin{array}{l}\text { Feedback should be given from time to } \\
\text { time while the homework is being } \\
\text { completed. }\end{array}$ & .50 & & & & & .63 \\
\hline & 7 & 39 & $\begin{array}{l}\text { The energy and work spent evaluating } \\
\text { homework should be reflected in the } \\
\text { results. }\end{array}$ & .50 & & & & & .66 \\
\hline \multirow{7}{*}{ 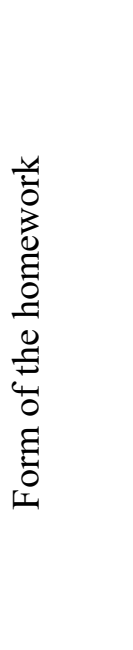 } & 8 & 34 & $\begin{array}{l}\text { In the process of doing the homework, } \\
\text { students should constantly interact with } \\
\text { their teachers. }\end{array}$ & .46 & & & & & .58 \\
\hline & 9 & 25 & Homework promotes creativity in students. & & .90 & & & & .64 \\
\hline & 10 & 24 & Homework should be interesting. & & .84 & & & & .60 \\
\hline & 11 & 26 & $\begin{array}{l}\text { Homework should be given with clear, well- } \\
\text { defined instructions. }\end{array}$ & & .66 & & & & .64 \\
\hline & 12 & 27 & $\begin{array}{l}\text { When giving homework, its difficulty level } \\
\text { should be appropriate for the students. }\end{array}$ & & .65 & & & & .61 \\
\hline & 13 & 23 & $\begin{array}{l}\text { When giving homework, the teacher should } \\
\text { talk with the students. }\end{array}$ & & .58 & & & & .58 \\
\hline & 14 & 28 & $\begin{array}{l}\text { Students should be motivated about the } \\
\text { outcomes of the homework when it is being } \\
\text { given to them. }\end{array}$ & & .53 & & & & .59 \\
\hline \multirow{3}{*}{ 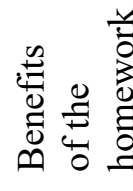 } & 15 & 9 & Homework improves self-respect. & & & .88 & & & .65 \\
\hline & 16 & 8 & Homework increases self-confidence. & & & .70 & & & .60 \\
\hline & 17 & 5 & Homework contributes to socialization. & & & .40 & & & .57 \\
\hline \multirow{5}{*}{ 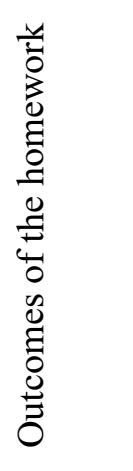 } & 18 & 18 & $\begin{array}{l}\text { Homework improves the ability to use } \\
\text { resources. }\end{array}$ & & & & .73 & & .60 \\
\hline & 19 & 15 & $\begin{array}{l}\text { Homework helps to consolidate prior } \\
\text { learning. }\end{array}$ & & & & .60 & & .61 \\
\hline & 20 & 17 & $\begin{array}{l}\text { Homework improves the ability to access } \\
\text { information. }\end{array}$ & & & & .55 & & .67 \\
\hline & 21 & 16 & $\begin{array}{l}\text { Homework improves the ability to study } \\
\text { independently. }\end{array}$ & & & & .46 & & .63 \\
\hline & 22 & 6 & $\begin{array}{l}\text { Homework develops a sense of } \\
\text { responsibility. }\end{array}$ & & & & .39 & & .61 \\
\hline
\end{tabular}


Table 3. Continues

\begin{tabular}{|c|c|c|c|c|c|c|c|c|c|}
\hline \multirow{9}{*}{ 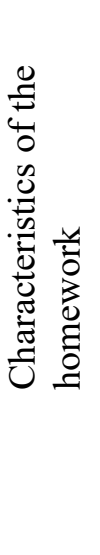 } & 23 & 4 & Homework contributes to make the lessons & & & & & .62 & .63 \\
\hline & 24 & 12 & $\begin{array}{l}\text { permanent. } \\
\text { Homework contributes to life-long learning }\end{array}$ & & & & & .61 & .58 \\
\hline & 25 & 2 & Homework supports learning. & & & & & .59 & .59 \\
\hline & 26 & 13 & Homework completes learning functions in & & & & & .58 & .64 \\
\hline & 27 & 1 & $\begin{array}{l}\text { Homework increases the time spent on } \\
\text { courses. }\end{array}$ & & & & & .50 & .44 \\
\hline & 28 & 3 & Homework increases the desire to study. & & & & & .48 & .61 \\
\hline & & \multicolumn{2}{|c|}{ Eigenvalue } & 10.76 & 2.64 & 1.49 & 1.18 & 1.09 & \\
\hline & & \multicolumn{2}{|c|}{ Explained variance (Total: 61.14\%) } & 38.24 & 9.45 & 5.33 & 4.21 & 3.90 & \\
\hline & & \multicolumn{2}{|c|}{ Cronbach's alpha (Total: .94) } & .86 & .89 & .79 & .86 & .82 & \\
\hline
\end{tabular}

As seen in Table 3, when the item-total correlation values for the items in the scale were analyzed, there was no item below .30 in the scale. When the items of the scale were analyzed individually, it was seen that the item-total correlations ranged between .44 and .67 . This result is one of the proofs that the items on the scale have high validity. When interpreting the itemtotal correlation, it can be said that items with .30 and the higher item-total correlation distinguish individuals well in terms of the measured feature (Büyüköztürk, 2019). Therefore, no items needed to be discarded in terms of item-total correlation values.

The scale in which the Direct Oblimin rotation technique was used had a five-factor structure. The contribution of the factors of the scale to the total variance was $38.24 \%$ for the first factor (process of doing homework), 9.45\% for the second factor (form of the homework), $5.33 \%$ for the third factor (benefits of the homework), $4.21 \%$ for the fourth factor (outcomes of the homework), and $3.90 \%$ for the fifth factor (characteristics of the homework). The total contribution of the five factors in the scale to the variance was calculated as $61.14 \%$.

The first factor (process of doing homework) of the HPHES consists of eight items $(37,35,36$, $38,40,33,39$, and 34 ) and the factor load values range from .46 to .65 . The second factor (form of the homework) consists of six items $(25,24,26,27,23$, and 28) and the factor load values range from .53 to .90 . The third factor (benefits of the homework) consists of three items $(9,8$, and 5) and the factor load values range between .40 and .88. The fourth factor (outcomes of the homework) consists of five items $(18,15,17,16$, and 6$)$, and the factor load values vary between .39 and .73. The fifth factor (characteristics of the homework) consists of six items $(4,12,2$, 13,1 , and 3 ) and the factor load values range between .48 and .62. In scale development studies, items with factor loads of .45 and higher in the scale are accepted as a good measure (Büyüköztürk, 2019). However, it is stated that items above 0.30 can be included in the scale (Kline, 2014). In terms of factor load values, the factor loads in the HPHES were .39 and higher.

The Cronbach's alpha reliability coefficients were .86 for the first factor (process of doing homework), .89 for the second factor (form of the homework), .79 for the third factor (benefits of the homework), .86 for the fourth factor (outcomes of the homework), and .82 for the fifth factor (characteristics of the homework). When all the items in the scale were evaluated together, the Cronbach's alpha reliability coefficient was .94. These values showed that the data collected by the scale had internal consistency.

The scree plot for the HPHES, which has a five-factor structure with a total of twenty-eight items, was also examined since the number of samples was over 300 (Field, 2005). Figure 1 shows the scree plot of the HPHES. 
Figure 1. Scree Plot.

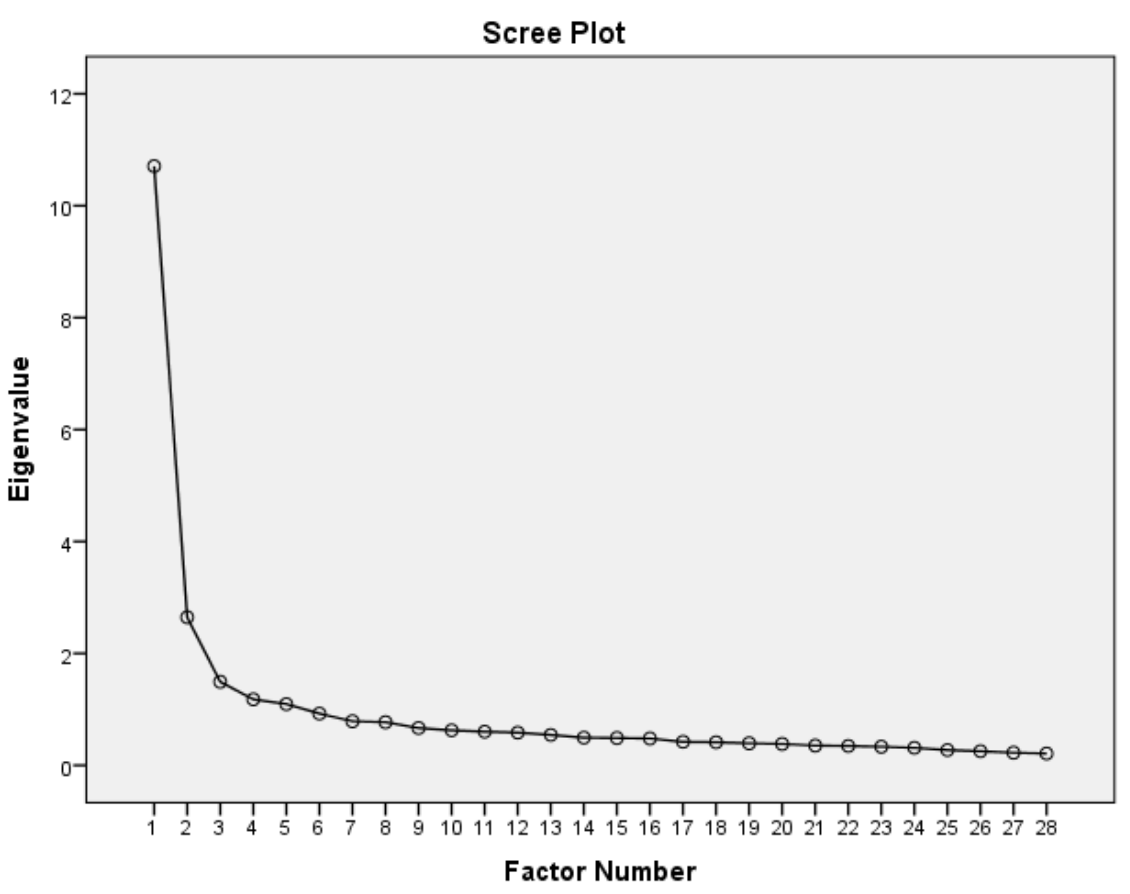

In Figure 1 (the scree plot), the slope reaches a plateau after the fifth point. There are five factors with eigenvalues above 1 and the scree plot supports this finding.

Table 4. Arithmetic mean, standard deviation values and correlation coefficients for factors $(n=368)$

\begin{tabular}{lllllllll}
\hline Factor & $\bar{x}$ & $d f$ & Total & Process & Form & Benefits & \multicolumn{2}{l}{ Outcomes } \\
\hline Total & 3.29 & .73 & 1 & $.84^{* *}$ & $.73^{* *}$ & $.79^{* *}$ & $.81^{* *}$ & $.81^{* *}$ \\
Process & 3.25 & .79 & & 1 & $.65^{* *}$ & $.57^{* *}$ & $.57^{* *}$ & $.60^{* *}$ \\
Form & 3.24 & .99 & & & 1 & $.40^{* *}$ & $.44^{* *}$ & $.41^{* *}$ \\
Benefits & 3.01 & 1.04 & & & & 1 & $.56^{* *}$ & $.59^{* *}$ \\
Outcomes & 3.69 & .87 & & & & & 1 & $.66^{* *}$ \\
Characteristics & 3.27 & .86 & & & & & & 1 \\
\hline
\end{tabular}

As seen in Table 4, the correlation values between the score for the whole scale and the five factors, and between the factors, were high and there was a significant relationship between these values at a level of .01. Correlation coefficients varied between .40 and .84 . These results demonstrate that all of the factors and the scale measured a similar structure.

\subsubsection{Confirmatory Factor Analysis}

The scale was tested with CFA in order to verify the 28 item and five-factor structure. The diagram obtained as a result of CFA is given in Figure 2 below. As a result of the model obtained, the compatibility index of the scale was examined. According to the findings, the model can be accepted because the RMSEA and SRMR values are lower than 0.08 while the CFI and TLI values are higher than 90 (Kline, 2015). 
Figure 2. CFA Diagram for the HPHES.

.78

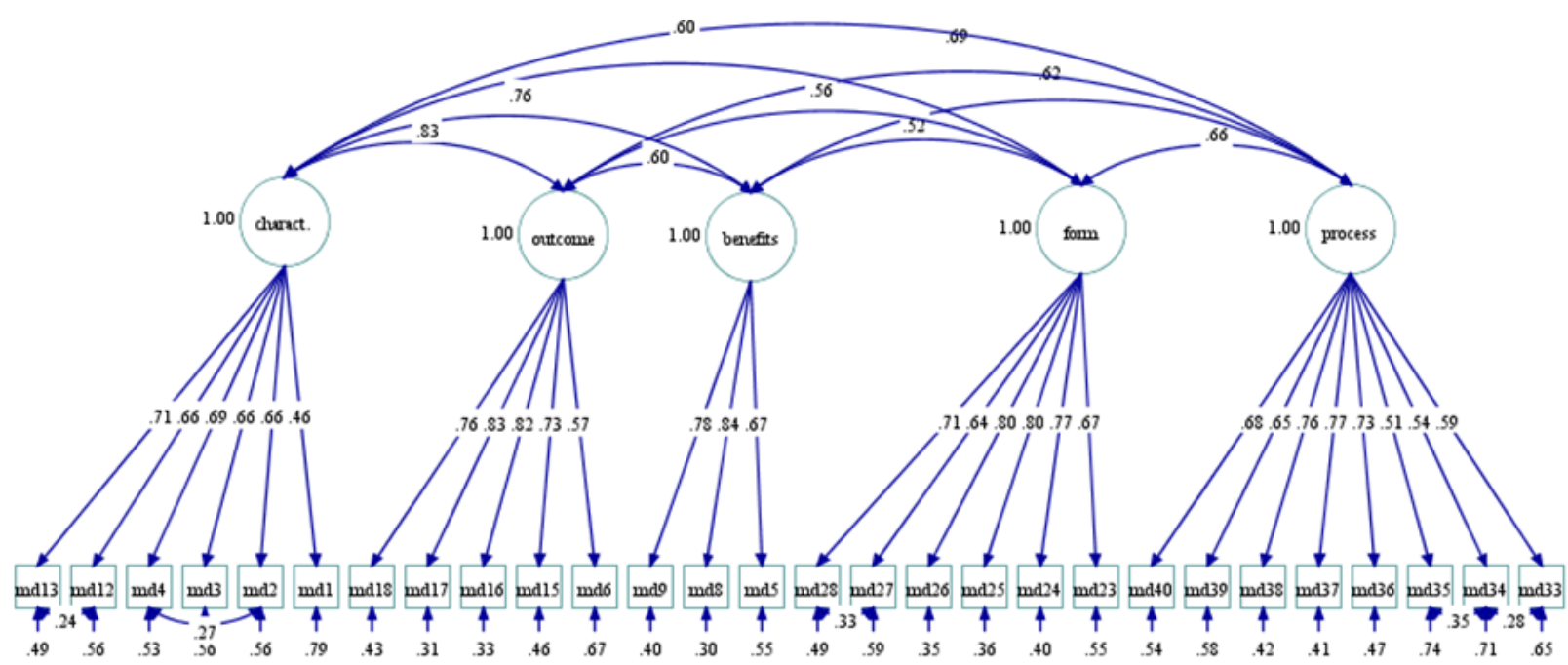

As a result of the CFA of the scale, the model can be accepted because the RMSEA and SRMR were lower than 0.08 and the CFI and TLI were higher than $90\left(\chi^{2} / d f=2.38<4\right.$; CFI $=0.92$; $\mathrm{TLI}=0.91$; RMSEA $=0.05$; SRMR=0.05). Figure 2 shows the factor loads of each item. Since there was a high correlation between some items related to the same factor in the model, the error measurements of the items were linked. As a result of the model, it was observed that the factor loads of each item were significant.

To determine the item discrimination of the items in the scale, the mean scores of the items were determined and item analysis was performed on the low $27 \%$ group and high $27 \%$ group. The difference between the mean group scores was analyzed using the independent groups $\mathrm{t}$ test. The analysis is given in Table 5.

Table 5. Item analysis results for low $27 \%$ and high \%27 groups' means.

\begin{tabular}{cccccccc}
\hline & $\begin{array}{c}t \\
\text { Low } \\
27 \% \text {-high } \\
\% 27)\end{array}$ & Item No & $\begin{array}{c}t \\
\text { (Low } \\
\text { 27\%-high } \\
\% 27)\end{array}$ & Item No & $\begin{array}{c}t \\
\text { 27\%-high } \\
\% 27)\end{array}$ & Item No & $\begin{array}{c}t \\
\text { 27\%-high } \\
\% 27)\end{array}$ \\
\hline 1 & $8.15^{*}$ & 9 & $14.40^{*}$ & 23 & $11.02^{*}$ & 34 & $11.91^{*}$ \\
2 & $13.41^{*}$ & 12 & $14.67^{*}$ & 24 & $14.44^{*}$ & 35 & $10.11^{*}$ \\
3 & $14.14^{*}$ & 13 & $14.54^{*}$ & 25 & $13.91^{*}$ & 36 & $13.51^{*}$ \\
4 & $11.85^{*}$ & 15 & $13.10^{*}$ & 26 & $14.02^{*}$ & 37 & $13.72^{*}$ \\
5 & $14.09^{*}$ & 16 & $14.48^{*}$ & 27 & $11.97^{*}$ & 38 & $16.12^{*}$ \\
6 & $11.12^{*}$ & 17 & $13.20^{*}$ & 28 & $15.32^{*}$ & 39 & $12.65^{*}$ \\
8 & $13.92^{*}$ & 18 & $12.01^{*}$ & 33 & $11.63^{*}$ & 40 & $14.20^{*}$ \\
\hline
\end{tabular}

$\left({ }^{1} \mathrm{n}=400{ }^{2} \mathrm{n}_{1}=\mathrm{n}_{2}=108{ }^{*} p<.001\right)$

As seen in Table 5, there is a statistically significant difference between the upper and lower groups of $27 \%$ for all items in the scale, and it is seen that t-values are significant $(p<.001)$. These results show that scale items have high item discrimination, high validity and are items to measure the same behavior.

Another operation after verifying the structure of the scale with CFA; in addition to Cronbach's Alpha internal consistency coefficient, the reliability of the scale is tested with a composite reliability coefficient. The composite reliability coefficients were .90 for the first factor (process of doing homework), .95 for the second factor (form of the homework), .92 for the third factor 
(benefits of thehomework), .90 for the fourth factor (outcomes of the homework), and .86 for the fifth factor (characteristics of the homework). When all the items in the scale were evaluated together, the composite reliability coefficient was .94. Composite reliability is calculated by factor loads and error rates obtained as a result of confirmatory factor analysis. It is suggested that compound reliability should be .70 and above (Hair, Anderson, Tatham, \& Black, 1998). In addition, the AVE value calculated for each factor of the scale is over .05.

The average variance extracted (AVE) value was .52 for the first factor (process of doing homework), .77 for the second factor (form of the homework), .80 for the third factor (benefits of thehomework), .64 for the fourth factor (outcomes of the homework), and .51 for the fifth factor (characteristics of the homework). An AVE value at least 0.5 indicates sufficient convergent validity (Henseler, Rinle, \& Sinkovics, 2009). Convergent validity is important in terms of showing that a certain structure has emerged (Şencan, 2020).

\section{DISCUSSION, CONCLUSION and RECOMMENDATIONS}

Homework is a task given to students to complete in their extra-curricular time (Cooper, 1989; Li et al., 2018) which increase their self-management, self-discipline, time management and independent problem-solving skills, and curiosity (Cooper, 1989; Li et al, 2018). Doing homework is considered important in higher education due to its effect on the educational process. This scale, which was specifically developed for university students, will contribute to the literature on homework in higher education.

The HPHES has a five-factor structure with twenty-eight items. The scale's factors are "process of doing homework", "form of the homework", "benefits of the homework", "outcomes of the homework", and "characteristics of the homework". The first factor (the process of doing homework) consists of eight items, the second factor (the form of the homework) consists of six items, the third factor (benefits of the homework) consists of three items, the fourth factor (outcomes of the homework) consists of five items, and the fifth factor (characteristics of the homework) consists of six items. The total contribution of the factors of HPHES to variance is $61.14 \%$.

When all the factors in the scale were evaluated together, the Cronbach's alpha reliability coefficient calculated was found to be .94 . Accordingly, the data collected with the scale has internal consistency. It was concluded that the correlation values between the score for the whole HPHES and the five factors, and between the factors, were high and that there was a significant relationship between these values at the level of .01. The correlation coefficients varied between .40 and .84 . These results indicate that all of the factors and the scale measure a similar structure.

The model can be accepted as the RMSEA and SRMR are lower than 0.08 and the CFI and TLI values are greater than $90\left(\chi^{2} / d f=2.36<4 ; \mathrm{CFI}=0.91\right.$; TLI $\left.=0.90 ; \mathrm{RMSEA}=0.05 ; \mathrm{SRMR}=0.05\right)$ according to the CFA which was conducted to confirm the five-factor, 28-item structure of the HPHES as a result of EFA.

A statistically significant difference was found between the groups in the $27 \%$ low and high analysis for the scale items and the $t$ value was significant $(p<.001)$. The item-total correlations of the items on the scale ranged from .44 to .67. These results showed that the scale items have high item discrimination and high validity, and that they measure the same behavior.

Cronbach's Alpha reliability coefficient results calculated for the scale were verified with composite reliability coefficients. Composite reliability coefficient calculated for the whole scale was found to be .94 . In addition, the AVE value calculated for each factor of the scale is over .05. 
These analyses were carried out to demonstrate the validity and reliability of the HPHES. Its structure was determined to be that of a scale with 28 items and five factors. The findings showed that the scale can provide valid and reliable results. The Turkish version of scale is given in Table A1 in the appendix part.

In the chaotic atmosphere caused by the recent coronavirus pandemic, the homework given at universities has gained importance. Distance education includes both homework and exams. The HPHES developed within the scope of this study will contribute to providing feedback on how homework is perceived by students. This feedback could also be used to improve the application. The subject of homework in higher education can also be examined using the HPHES in terms of different variables.

\section{Declaration of Conflicting Interests and Ethics}

The author(s) declare no conflict of interest. This research study complies with research publishing ethics. The scientific and legal responsibility for manuscripts published in IJATE belongs to the author(s).

\section{Authorship contribution statement}

Veda Yar Yıldırım: All the research process (Investigation, Resources, Data collecting, Visualization, Software, Formal Analysis, and Writing the original draft, Methodology, Supervision, and Validation).

\section{ORCID}

Veda Yar Yildırım (DD https://orcid.org/0000-0002-2129-4189

\section{REFERENCES}

Arıkan, Y. D., \& Altun, E. (2007). Sınıf ve okul öncesi öğretmen adaylarının çevrimiçi ödev sitelerini kullanımına yönelik bir araştırma [A research on preschool and primary studentteachers' use of online homework sites]. Elementary Education Online, 6(3), 366376.

Arkonaç, S. A. (1998). Psikoloji (zihin süreçleri bilimi) [Psychology (science of mind processes)]. Alfa.

Balbuena, S. E., \& Lamela, R. A. (2015). Prevalence, motives, and views of academic dishonesty in higher education. Online Submission, 3(2), 69-75.

Balc1, A. (2004). Sosyal bilimlerde araştırma (4. Bask1) [Research in social sciences]. Pegem.

Baran, A. (2019). Home improvement: Look at the historical role of homework in education, where we are today, and what schools need to consider as they evaluate their approach. Independent School, 78(2), 44.

Bembenutty, H. (2005). Predicting homework completion and academic achievement: The role of motivational beliefs and self-regulatory processes [Unpublished doctoral dissertation]. City University of New York.

Beumann, S., \& Wegner, S.-A. (2018). An outlook on self-assessment of homework assignments in higher mathematics education. International Journal of STEM Education, 5, 55. https://doi.org/10.1186/s40594-018-0146-Z

Büyüköztürk, Ş. (2019). Sosyal bilimler için veri analizi el kitabı (25. Baskı) [Manual of data analysis for social sciences]. Pegem.

Çakır, E., \& Ünal, A. (2019). An investigation into middle school students' conceptions of homework. Language Teaching and Educational Research (LATER), 2(1), 41-56. https://doi.org/10.35207/later.535622

Can, A. (2014). SPSS ile bilimsel araştırma sürecinde nicel veri analizi [Quantitative data analysis in the scientific research process with SPSS]. Pegem. 
Çokluk, Ö., Şekercioğlu, G., \& Büyüköztürk, Ş. (2010). Sosyal bilimler için çok değişkenli istatistik [Multivariate statistics for social sciences]. Pegem.

Cooper, H. (1989). Homework. Longman.

Cooper, H. (2001). Homework for all-in moderation. Educational Leadership, 58(7), 34.

Cooper, H., \& Kalish, N. (2015). Should schools give summer homework? New York Times Upfront, 147(13), 22.

Edinsel, K. (2008). Bologna Süreci'nin Türkiye'de Uygulanması "Bologna Uzmanları Ulusal Takımı Projesi" 2007-2008 Sonuç Raporu [Implementation of the Bologna Process in Turkey "Bologna Experts National Team Project" 2007-2008 Final Report]. http://w3.gazi.edu.tr/ gyavuzcan/documents/1.pdf

Field, A. P. (2005). Discovering statistics using SPSS (2nd ed.). Sage.

Flunger, B., Trautwein, U., Nagengast, B., Lüdtke, O., Niggli, A., \& Schnyder, I. (2017). A person-centered approach to homework behavior: Students' characteristics predict their homework learning type. Contemporary Educational Psychology, 48, 1-15.

Furst, R. T., Evans, D. N., \& Roderick, N. M. (2018). Frequency of college student smartphone use: impact on classroom homework assignments. Journal of Technology in Behavioral Science, 3(2), 49-57. https://doi.org/10.1007/s41347-017-0034-2.

Gündüz, Ş. (2005). Geleneksel çevrimiçi ve bireysel işbirliğine dayalı ödev uygulamalarının lisans öğrencilerinin akademik başarılarına ve ödeve ilişkin tutumlarına etkisi [The effects of traditional online and individual cooperative homework on undergraduate students` academic achievement and attitude towark homework] [Unpublished doctoral dissertation]. Anadolu University.

Hair, J. F., Anderson, E. R., Tatham, L. R., \& Black, W. C. (1998). Multivariate data analysis. Prentice Hall.

Henseler, J., Ringle, C. M., \& Sinkovics, R. R. (2009). The use of partial least squares path modeling in international marketing. In Rudolf R. Sinkovics \& Pervez N. Ghauri (Eds.), New Challenges to International Marketing (C. 20, ss. 277-319). Emerald Group Publishing Limited. https://doi.org/10.1108/S1474-7979(2009)0000020014

Ho, R. (2006). Handbook of univariate and multivariate data analysis and interpretation with SPSS. CRC Press.

Hyman, L.M., Superville, C.R., Ramsey, V.J., \& Williams, J.H. (2005). Using control charting to evaluate and reinforce student learning in accounting. International Journal of Management, 22(1), 41-48.

Kline, P. (2014). An easy guide to factor analysis. Routledge.

Kline, R. B. (2015). Principles and practice of structural equation modeling. Guilford publications.

Li, W., Bennett, R. M., Olsen, T., \& McCord, R. (2018). Engage engineering students in homework: attribution of low completion and suggestions for interventions. American Journal of Engineering Education, 9(1), 23-38.

Murillo, F. J., \& Martinez-Garrido, C. (2014). Homework and primary-school students' academic achievement in Latin America. International Review of Education, 60(5), 661681. https://doi.org/10.1007/s11159-014-9440-2

Murtagh, L. (2010). They give us homework! Transition to higher education: The case of initial teacher training. Journal of Further and Higher Education, 34(3), 405-418. https://doi.org/10.1080/0309877X.2010.484057

Núñez, J. C., Suárez, N., Rosário, P., Vallejo, G., Cerezo, R., \& Valle, A. (2015). Teachers' feedback on homework, homework-related behaviors, and academic achievement. The Journal of Educational Research, 108(3), 204-216. 
Reisimer, E. L. (1999). The relationship between parental attitudes on homework and homework return rates in kindergarten [Unpublished master thesis]. University of Wisconsin - Stout the Graduate College.

Şen, Z., Uludağ, G., Kavak, Y., \& Seferoğlu, S. S. (2016). Bologna süreciyle ilgili bir inceleme: Öğrenci başarısını değerlendirme yöntemleri ile öğrenci iş yükünün karşılaştırılması [An investigation regarding the Bologna process: Comparison of student assessment methods and student workload]. Journal of Higher Education, 6(2), 84-94.

Şencan, H. (2005). Sosyal ve davranışsal ölçümlerde güvenirlilik ve geçerlilik [Reliability and validity in social and behavioral measurements]. Seçkin.

Şencan, H. (2020, 25 Mayıs). Veri analizi [Data analysis]. https://ders.es/tez/gecerlilik_analizl eri.html

Tabachnick, B. G., \& Fidell, L. S. (2001). Using multivariate statistics (4th ed.). Allyn and Bacon.

Turkish Language Assosication, (2020). Turkish language association dictionaries. Retrieved February 20, 2020, from https://sozluk.gov.tr/

Türkoğlu, A., İflazoğlu, A., \& Karakuş, M. (2007). İlköğretimde ödev [Homework in primary education]. Morpa Kültür.

Ünal, A., Yıldırım, A., \& Sürücü, A. (2018). Eğitim Fakültesi Öğrencilerinin etkili olarak kabul ettikleri ödevler [Homework accepted as effective by the students of the faculty of education]. Mehmet Akif Ersoy University Journal of Education Faculty, 48, 555-574.

Velicer, W. F., \& Fava, J. L. (1998). Affects of variable and subject sampling on factor pattern recovery. Psychological Methods, 3(2), 231-251. https://doi.org/10.1037/1082-989X.3.2 .231

Xu, J., Fan, X., \& Du, J. (2018). A study of the validity and reliability of the online homework emotion regulation scale. Measurement, 115, 243-248. https://doi.org/10.1016/j.measure ment.2017.10.050

Yapıcı, N. (1995). İlkokullarda öğretmen-öğrenci ve velilerinin ev ödevi konusundaki görüşlerinin belirlenmesi [Determining the opinions of teachers, students, and parents about homework in primary schools] [Unpublished master's thesis]. Ankara University.

Yar Yıldırım, V. (2018). Öğretmen, öğrenci ve velilerin ortaokul düzeyinde verilen günlük ödevler hakkındaki görüşleri [The opinions of the students, teachers, and parents about the daily assingments given at secondary school level]. Milli Eğitim Dergisi, 220, 201224.

Young, J. R. (2002). Homework? What homework. The Chronicle of Higher Education, 49(15), A35-A37. 


\section{APPENDIX}

Table A1. Turkish version of the scale.

\begin{tabular}{|c|c|c|c|c|c|c|c|}
\hline \multicolumn{8}{|c|}{ Yükseköğretimde Ödev Süreci Ölçeği (YÖSÖ) } \\
\hline \multirow[t]{2}{*}{ 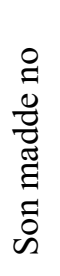 } & \multirow[t]{2}{*}{ 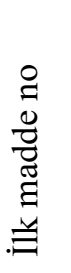 } & \multirow[t]{2}{*}{ MADDELER } & 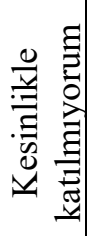 & 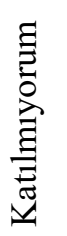 & 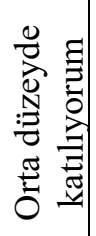 & 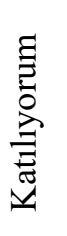 & 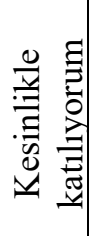 \\
\hline & & & 1 & 2 & 3 & 4 & 5 \\
\hline 1 & 37 & Yapılan ödevlere ilișkin dönütler yapıcıdır. & 1 & 2 & 3 & 4 & 5 \\
\hline 2 & 35 & $\begin{array}{l}\text { Ödevin yapılma sürecinde gerekli dönütler için hocalar } \\
\text { öğrencilere yeterli zamanı ayırmaktadırlar. }\end{array}$ & 1 & 2 & 3 & 4 & 5 \\
\hline 3 & 36 & $\begin{array}{l}\text { Ödev yapma süreci başka kazanımları da beraberinde } \\
\text { getirmektedir. }\end{array}$ & 1 & 2 & 3 & 4 & 5 \\
\hline 4 & 38 & Ödev süreci sonunda öğrencide başarı hazzı oluşmaktadır. & 1 & 2 & 3 & 4 & 5 \\
\hline 5 & 40 & $\begin{array}{l}\text { Ödevler öğretim süreci sonunda tüm yaşamda } \\
\text { kullanılmaktadır. }\end{array}$ & 1 & 2 & 3 & 4 & 5 \\
\hline 6 & 33 & $\begin{array}{l}\text { Ödevin yapılma sürecinde zaman zaman dönütler } \\
\text { verilmektedir. }\end{array}$ & 1 & 2 & 3 & 4 & 5 \\
\hline 7 & 39 & $\begin{array}{l}\text { Ödevlerin değerlendirilmesinde gösterilen emek, çaba, } \\
\text { sonuca yansımaktadır }\end{array}$ & 1 & 2 & 3 & 4 & 5 \\
\hline 8 & 34 & $\begin{array}{l}\text { Ödevin yapılma sürecinde öğrenciler hocalarla sürekli } \\
\text { etkileşim halindedirler. }\end{array}$ & 1 & 2 & 3 & 4 & 5 \\
\hline 9 & 25 & $\begin{array}{l}\text { Ödevler verilirken öğrencide yaratıcılığa teşvik edici } \\
\text { nitelikte olması dikkate alınmaktadır. }\end{array}$ & 1 & 2 & 3 & 4 & 5 \\
\hline 10 & 24 & Ödevler ilgi çekici nitelikte verilmektedir. & 1 & 2 & 3 & 4 & 5 \\
\hline 11 & 26 & $\begin{array}{l}\text { Ödevler açık, iyi tanımlanmış bir yönergeyle } \\
\text { verilmektedir. }\end{array}$ & 1 & 2 & 3 & 4 & 5 \\
\hline 12 & 27 & $\begin{array}{l}\text { Ödevler verilirken öğrencinin yapabileceği zorlukta olmas1 } \\
\text { dikkate alınmaktadır. }\end{array}$ & 1 & 2 & 3 & 4 & 5 \\
\hline 13 & 23 & Ödev verilme sürecinde öğrenciyle istişare edilmektedir. & 1 & 2 & 3 & 4 & 5 \\
\hline 14 & 28 & $\begin{array}{l}\text { Ödevler verilme sürecinde ödevin kazanımları konusunda } \\
\text { öğrenciler motive edilmektedir. }\end{array}$ & 1 & 2 & 3 & 4 & 5 \\
\hline 15 & 9 & Ödev, özsaygıyı artırmaktadır. & 1 & 2 & 3 & 4 & 5 \\
\hline 16 & 8 & Ödev, özgüveni artırmaktadır. & 1 & 2 & 3 & 4 & 5 \\
\hline 17 & 5 & Ödev, sosyalleşmeye katkıda bulunmaktadır. & 1 & 2 & 3 & 4 & 5 \\
\hline 18 & 18 & $\begin{array}{l}\text { Ödev, mevcut kaynakları kullanma becerisini } \\
\text { geliştirmektedir. }\end{array}$ & 1 & 2 & 3 & 4 & 5 \\
\hline 19 & 15 & Ödev öğrenilenleri pekiştirmektedir. & 1 & 2 & 3 & 4 & 5 \\
\hline 20 & 17 & Ödev, bilgiye ulaşma becerisini geliştirmektedir. & 1 & 2 & 3 & 4 & 5 \\
\hline 21 & 16 & Ödev, bağımsız çalışma becerisini geliştirmektedir. & 1 & 2 & 3 & 4 & 5 \\
\hline 22 & 6 & Ödev, sorumluluk duygusu kazandırmaktadır. & 1 & 2 & 3 & 4 & 5 \\
\hline 23 & 4 & $\begin{array}{l}\text { Ödev, derste yapılanları kalıcı hale getirmekte katkıda } \\
\text { bulunmaktadır. }\end{array}$ & 1 & 2 & 3 & 4 & 5 \\
\hline 24 & 12 & Ödev, yaşam boyu öğrenmeye katkıda bulunmaktadır. & 1 & 2 & 3 & 4 & 5 \\
\hline 25 & 2 & Ödev, öğrenmeyi desteklemektedir. & 1 & 2 & 3 & 4 & 5 \\
\hline 26 & 13 & $\begin{array}{l}\text { Ödev, öğretimde öğrenme fonksiyonlarını tamamlama } \\
\text { özelliği bulunmaktadır. }\end{array}$ & 1 & 2 & 3 & 4 & 5 \\
\hline 27 & 1 & Ödev, ders için ayrılan zamanı çoğaltmaktadır. & 1 & 2 & 3 & 4 & 5 \\
\hline 28 & 3 & Ödev, çalışma isteğini artırmaktadır. & 1 & 2 & 3 & 4 & 5 \\
\hline
\end{tabular}

